NATIONAL LABORATORY

\title{
Evaluation of Application Space Expansion for the Sensor Fish
}

February 2014

\section{Prepared by}

Chris DeRolph, MS

Mark Bevelhimer, PhD

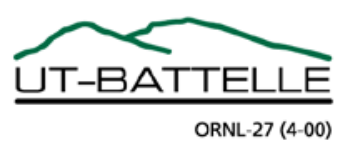




\section{DOCUMENT AVAILABILITY}

Reports produced after January 1, 1996, are generally available free via US Department of Energy (DOE) SciTech Connect.

Website http://www.osti.gov/scitech/

Reports produced before January 1, 1996, may be purchased by members of the public from the following source:

National Technical Information Service

5285 Port Royal Road

Springfield, VA 22161

Telephone 703-605-6000 (1-800-553-6847)

TDD 703-487-4639

Fax 703-605-6900

E-mail info@ntis.gov

Website http://www.ntis.gov/support/ordernowabout.htm

Reports are available to DOE employees, DOE contractors, Energy Technology Data Exchange representatives, and International Nuclear Information System representatives from the following source:

Office of Scientific and Technical Information

PO Box 62

Oak Ridge, TN 37831

Telephone 865-576-8401

Fax 865-576-5728

E-mail reports@osti.gov

Website http://www.osti.gov/contact.html

This report was prepared as an account of work sponsored by an agency of the United States Government. Neither the United States Government nor any agency thereof, nor any of their employees, makes any warranty, express or implied, or assumes any legal liability or responsibility for the accuracy, completeness, or usefulness of any information, apparatus, product, or process disclosed, or represents that its use would not infringe privately owned rights. Reference herein to any specific commercial product, process, or service by trade name, trademark, manufacturer, or otherwise, does not necessarily constitute or imply its endorsement, recommendation, or favoring by the United States Government or any agency thereof. The views and opinions of authors expressed herein do not necessarily state or reflect those of the United States Government or any agency thereof. 
Environmental Sciences Division

\title{
EVALUATION OF APPLICATION SPACE EXPANSION FOR THE SENSOR FISH
}

Chris DeRolph and Mark S. Bevelhimer*

Date Published: February 2014

\author{
Prepared by \\ OAK RIDGE NATIONAL LABORATORY \\ Oak Ridge, Tennessee 37831-6283 \\ managed by \\ UT-BATTELLE, LLC \\ for the \\ U.S. DEPARTMENT OF ENERGY \\ under contract DE-AC05-00OR22725
}





\section{CONTENTS}

LIST OF FIGURES
LIST OF TABLES
ABSTRACT
ACKNOWLEDGMENTS
1.




\section{LIST OF FIGURES}

Figure $\quad$ Page

Figure 1. Hydropower plant locations across the lower 48 states in the United States................................ 2

Figure 2: Turbine rated head (ft) for different turbine types in the NHAAP database. .............................. 4

Figure 3. Average turbine threat ranking for hydropower plants............................................................ 6

Figure 4. Number of key migratory species that have the potential to occur at each hydropower

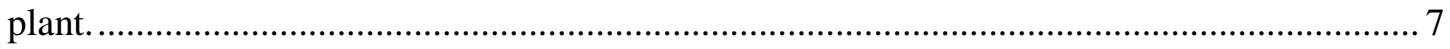

\section{LIST OF TABLES}

Table

Page

Table 1. List of turbine types and their potential to impact fish during passage ........................................ 3

Table 2. List of fish species that occur in the lower 48 states that were considered key migratory

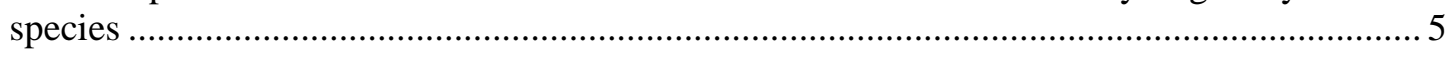

Table 3. Example list of hydropower plants with relatively high turbine threat to fish, key migratory species occurrence potential, and generation capacity ........................................................... 8

Table 4. Example list of key migratory species by plant .................................................................... 9 


\begin{abstract}
The Pacific Northwest National Laboratory has developed an instrument known as the sensor fish that can be released into downstream passage routes at hydropower facilities to collect data on the physical conditions that a fish might be exposed to during passage through a turbine. The US Department of Energy Wind and Water Power Program sees value in expanding the sensor fish application space beyond large Kaplan turbines in the northwest United States to evaluate conditions to which a greater variety of fish species are exposed. Development of fish-friendly turbines requires an understanding of both physical passage conditions and biological responses to those conditions. Expanding the use of sensor fish into other application spaces will add to the knowledge base of physical passage conditions and could also enhance the use of sensor fish as a site-specific tool in mitigating potential impacts to fish populations from hydropower. The Oak Ridge National Laboratory (ORNL) National Hydropower Assessment Program (NHAAP) database contains hydropower facility characteristics that, along with national fish distribution data, were used to evaluate potential interactions between fish species and project characteristics related to downstream passage issues. ORNL developed rankings for the turbine types in the NHAAP database in terms of their potential to impact fish through injury or mortality during downstream turbine passage. National-scale fish distributions for 31 key migratory species were spatially intersected with hydropower plant locations to identify facilities where turbines with a high threat to fish injury or mortality overlap with the potential range of a sensitive fish species. A dataset was produced that identifies hydropower facilities where deployment of the sensor fish technology might be beneficial in addressing issues related to downstream fish passage. The dataset can be queried to target specific geographic regions, fish species, license expiration dates, generation capacity levels, ownership characteristics, turbine characteristics, or any combination of these metrics.
\end{abstract}




\section{ACKNOWLEDGMENTS}

This research was supported by the US Department of Energy's (DOE) OFFICE OF ENERGY EFFICIENCY and Renewable Energy, Water Power Program. ORNL is managed by UT-Battelle, LLC, for DOE under Contract DE-AC05-00OR22725. Thomas Heibel of BSC Incorporated provided project management for the DOE Wind and Water Power Program. PNNL collaborators Daniel Deng and Marshall Richmond provided ideas on study context and objectives. ORNL colleagues Shih-Chieh Kao, Ryan McManamay, and Qin Fen Zhang provided access to hydropower and environmental data and valuable insight. 


\section{INTRODUCTION}

\subsection{Overview}

The Pacific Northwest National Laboratory (PNNL) has developed an instrument known as the sensor fish that can be released into the intake of a hydropower turbine or other water passage route (e.g., spillway or sluiceway) to collect data on the physical conditions (e.g. water pressures, velocities, accelerations) that a fish might experience during passage through a hydropower turbine or other dam passage route into the dam tailwaters (Deng et al. 2007). The US Department of Energy Wind and Water Power Program (DOE-WWPP) is funding design enhancements in the sensor fish so that it might have wider application. To date, the sensor fish has been deployed mainly, but not exclusively, at dams with large Kaplan turbines on northwest river systems (Deng et al. 2010). However, there is value to expanding the sensor fish application space to include additional types and sizes of turbines to collect data on turbine passage conditions to which a greater variety of fish species are exposed.

The Oak Ridge National Laboratory (ORNL) National Hydropower Asset Assessment Program (NHAAP) (ORNL 2013) is an integrated energy, water, and ecosystem research effort for sustainable hydroelectricity generation and water management. The ORNL NHAAP database contains hydropower facility characteristics, such as turbine type, hydraulic head, and geographic location, which along with national fish distribution data can be used to evaluate potential interactions between fish species and project characteristics related to down-stream passage issues.

This report summarizes the results of an analysis performed by ORNL using the NHAAP database and publicly available fish distribution data to identify potential new application space for the sensor fish. Although fish distribution information is available for hundreds of species, this analysis focused on potential interactions between a subset of key migratory fish species and different turbine types.

\subsection{The value of identifying new application space for the sensor fish}

Development of environmentally advanced (i.e., fish-friendly) turbines requires an understanding of both physical passage conditions and biological responses to those conditions. Expanding the use of sensor fish into other application spaces (e.g., Francis turbines, Pelton turbines, small hydro projects) will add to the knowledge base of physical passage conditions (e.g., velocities, blade encounters, pressure changes, and sheer stresses) and could also enhance the use of sensor fish as a site-specific tool in mitigating potential impacts to fish populations from hydropower.

\section{METHODS}

\subsection{NHAAP Database Overview}

As part of the NHAAP database effort, ORNL integrates data from multiple data sources and compiles the most current, detailed, and spatially comprehensive information for analyzing and visualizing existing US hydropower assets. Existing hydropower asset data are housed within the NHAAP geographic information system at ORNL and are used to support various initiatives of the DOE-WWPP.

The NHAAP database design is both relational and hierarchical in structure and includes characteristics for hydropower plants, dams, and turbines. Data compilation and integration into the database is ongoing 
as new information is acquired, but the existing hydropower asset data compiled to date are more than adequate to perform a wide variety of analyses. Of the roughly 2,300 hydropower plants in the United States, over 1,800 have pertinent data (i.e., turbine types or key migratory species present) that justifies including them in this analysis (Figure 1).

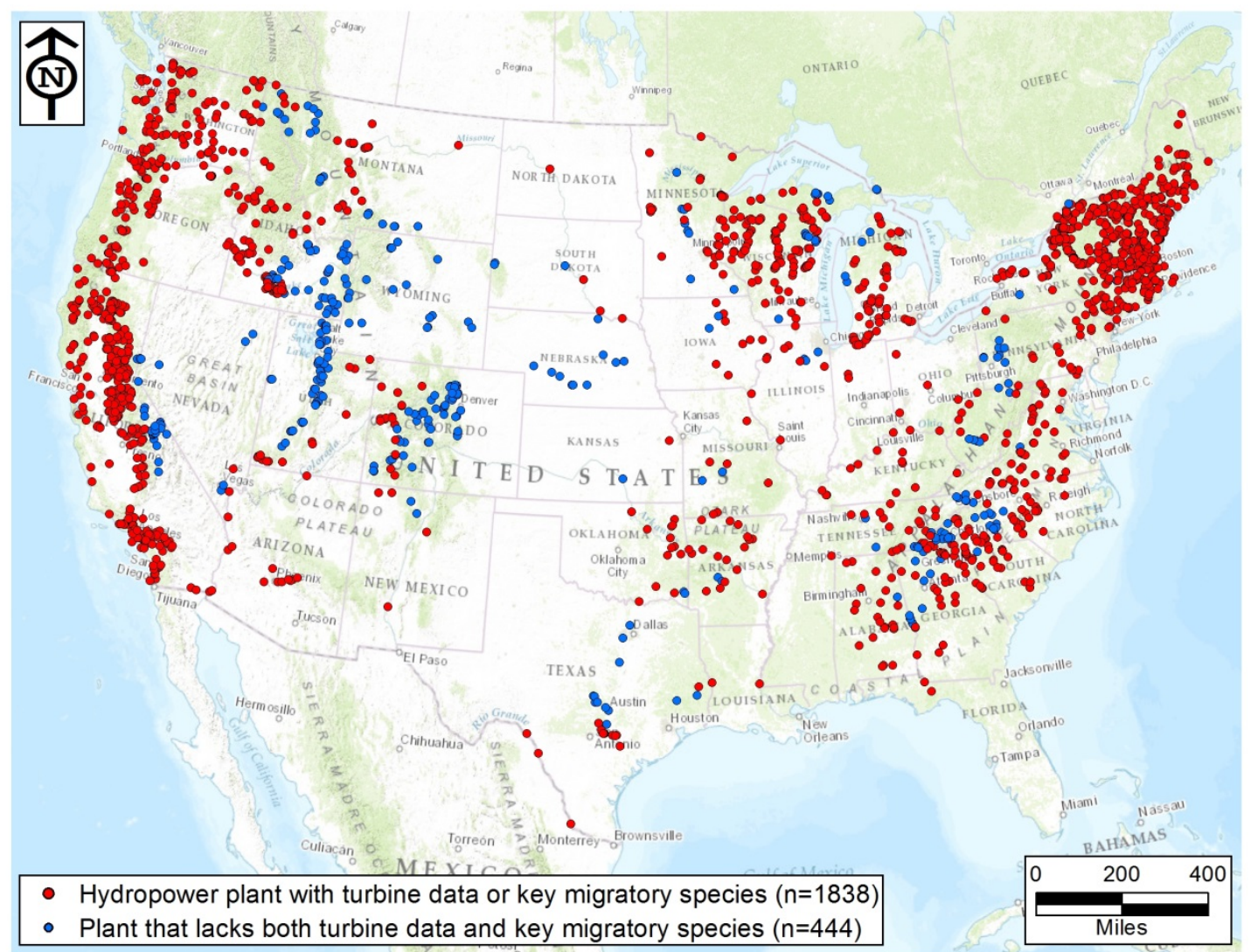

Figure 1. Hydropower plant locations across the lower 48 states in the United States.

\subsection{Applying a turbine threat ranking to different turbine types in the NHAAP database}

ORNL has done considerable research and assessment, including long-standing collaborations with PNNL, related to understanding turbine passage conditions for fish. Fish passing through a turbine are subjected to potentially lethal conditions in the form of pressure differentials (rapid decrease in pressure), turbulence and shearing forces, cavitation (below atmosphere pressure), and mechanical injury (abrasion, contusion, and blade strike) (Cada et al. 1997, Cada 2001). The degree of the injury is related to fish species and size, facility operating mode, and turbine characteristics. Turbine characteristics include turbine type, turbine design (e.g., the number of blades), power capacity, rated head, runner diameter, and rotational speed, and the accumulation of these characteristics results in the degree of threat to fish passing through a turbine.

The selection of turbine type, rotational speed, and runner diameter are dependent on the rated and operating ranges of hydraulic head and power (flow) capacity. It is generally more technically suitable and economically efficient to use high-speed turbine-generator units at high-head hydropower sites. High- 
speed turbines typically have more blades than lower speed turbines. Impulse turbines (Pelton and Turgo) with high-pressure jet flows are considered fatal to any entrained fishes, and thus require small screen sizes at water intakes. Low-head and low-speed turbine runners, designed with thicker and less-sharp wicket-gates and blades as well wider gaps between the parts, are more fish-friendly. The operating mode of a facility (peaking and pulsing) and mode changes could further complicate and aggravate the potential fish injury through adverse flow conditions, stress, and pressure differentials.

Based on ORNL personnel's knowledge of hydropower turbine selection and design, Table 1 ranks the turbine types in terms of their potential to impact fish through injury or mortality during downstream turbine passage. It should be noted that this order of threat ranking is relative for the same fish specifies and similar capacity scales of hydropower units. For example, a Francis turbine is not necessarily less impactful than a Pelton turbine for a particular fish species, if the Pelton turbine is installed at a small hydropower site with 300 feet of rated head and a large Francis turbine is installed at a large hydro site with 1,000 feet of rated head. There is significant overlap in the application ranges of different turbine types. Figure 2 shows the head ranges of different turbine types using the existing hydropower plant data taken from the NHAAP database.

Each turbine in the NHAAP database for which turbine-type data have been acquired $(n=4,777)$ was assigned a threat ranking of one (lower risk) to seven (higher risk) based on fish impact potential as described in Table 1. A threat ranking was approximated for turbines for which turbine-type data have yet to be acquired but turbine-rated head values have been acquired $(n=169)$. Head values were approximated for these turbines by transforming all head values into a range of 1 to 7 . It was assumed that turbines with higher fish impact potential were typically installed at dams with higher head. Once threat rankings were assigned to turbines, an average threat ranking was calculated for each plant and this average was transformed to a value range of one to ten.

Table 1. List of turbine types and their potential to impact fish during passage

\begin{tabular}{|c|c|c|c|c|}
\hline Turbine type & $\begin{array}{l}\text { Rated } \\
\text { head }\end{array}$ & $\begin{array}{c}\text { Rotation } \\
\text { speed of } \\
\text { runner }\end{array}$ & $\begin{array}{l}\text { No. of } \\
\text { blades }\end{array}$ & $\begin{array}{c}\text { Fish impact } \\
\text { potential }\end{array}$ \\
\hline Pelton & High & Fast & Many & High (7) \\
\hline Francis & & & & \\
\hline Deriaz or diagonal flow & & & & \\
\hline Cross flow & & & & \\
\hline Kaplan & & & & \\
\hline Propeller & $\downarrow$ & $\downarrow$ & $\downarrow$ & $\downarrow$ \\
\hline Bulb/tubular & Low & Slow & Few & Low (1) \\
\hline
\end{tabular}




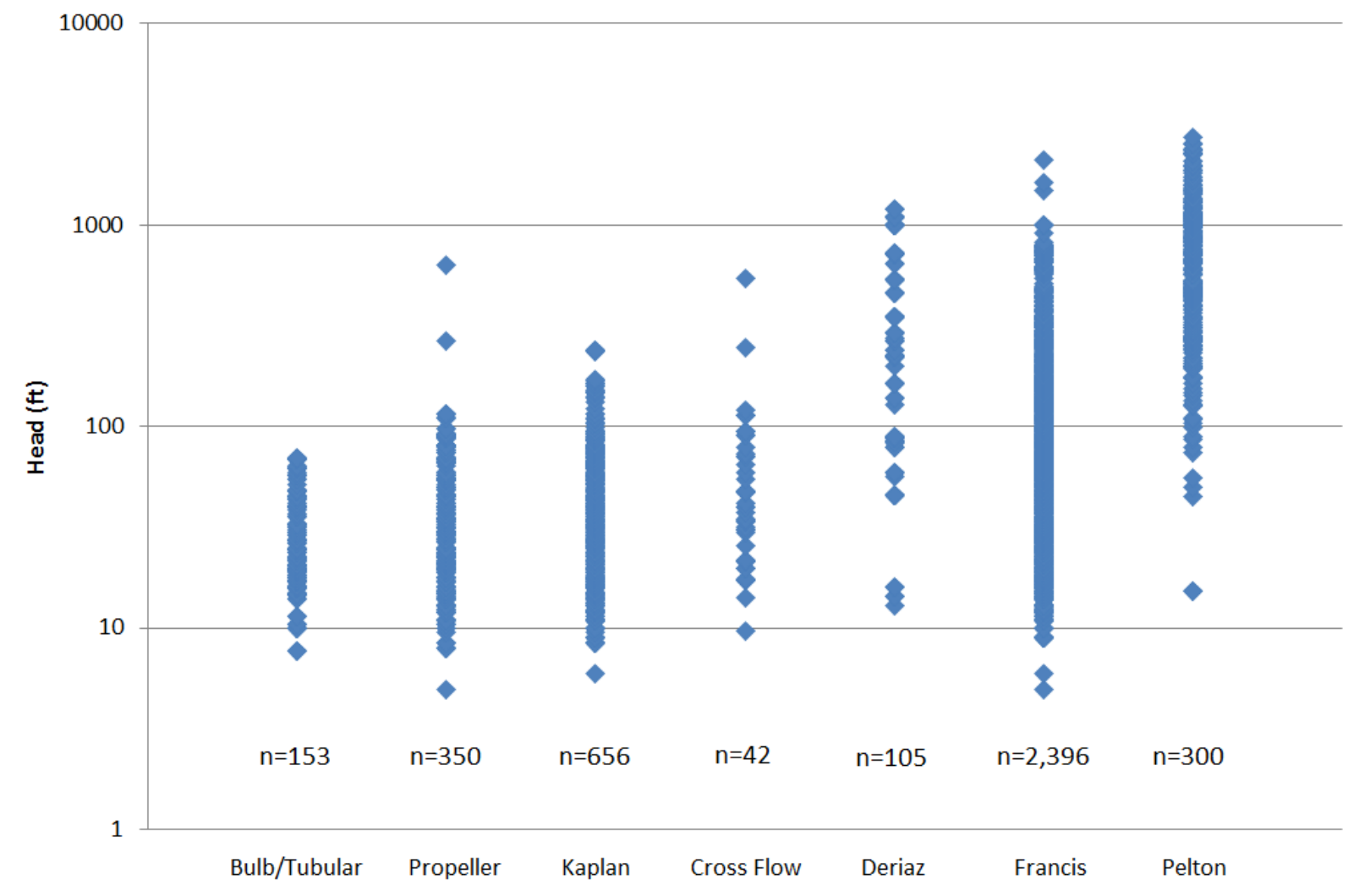

Figure 2: Turbine rated head (ft) for different turbine types in the NHAAP database.

\subsection{Linking distributions of key migratory fish species to turbine locations}

NatureServe (2010) has spent over a decade developing and refining a database of the current and historical distributions of freshwater fishes at the 8-digit hydrologic unit code (HUC) scale. The database includes information for over 800 species. The sensor fish application space analysis focused on 31 key migratory fish species representing 12 genera deemed highly important because of their migratory characteristics, level of protection, impaired status, or stakeholder interest (Table 2). The NatureServe database notes whether a species is native or introduced in each 8-digit HUC, and all introduced species were excluded from consideration in this analysis. The NatureServe database does not include Alaska or Hawaii, and thus those states were not included in this analysis. A spatial intersection analysis was performed at the 8-digit HUC scale to determine the potential presence or absence of each key migratory species at each hydropower plant location. 
Table 2. List of fish species that occur in the lower 48 states that were considered key migratory species

\begin{tabular}{ll}
\hline Scientific name & Common name \\
\hline Acipenser brevirostrum & Shortnose Sturgeon \\
Acipenser fulvescens & Lake Sturgeon \\
Acipenser medirostris & Green Sturgeon \\
Acipenser oxyrinchus & Atlantic Sturgeon \\
Acipenser transmontanus & White Sturgeon \\
Alosa aestivalis & Blueback Herring \\
Alosa mediocris & Hickory Shad \\
Alosa pseudoharengus & Alewife \\
Alosa sapidissima & American Shad \\
Anguilla rostrata & American Eel \\
Gila boraxobius & Borax Lake Chub \\
Gila cypha & Humpback Chub \\
Gila ditaenia & Sonora Chub \\
Gila elegans & Bonytail \\
Gila intermedia & Gila Chub \\
Gila nigrescens & Chihuahua Chub \\
Gila purpurea & Yaqui Chub \\
Gila seminuda & Virgin River Chub \\
Morone saxatilis & Striped Bass \\
Oncorhynchus gorbuscha & Pink Salmon \\
Oncorhynchus keta & Chum Salmon \\
Oncorhynchus kisutch & Coho Salmon \\
Oncorhynchus mykiss & Rainbow Trout or Steelhead \\
Oncorhynchus nerka & Sockeye Salmon \\
Oncorhynchus tshawytscha & Chinook Salmon \\
Petromyzon marinus & Sea Lamprey \\
Polyodon spathula & Paddlefish \\
Ptychocheilus lucius & Colorado Pikeminnow \\
Salmo salar & Atlantic Salmon \\
Thymallus arcticus & Arctic Grayling \\
Xyrauchen texanus & Razorback Sucker \\
\hline & \\
\hline
\end{tabular}

\section{RESULTS}

The spatial intersection analysis was used to produce turbine threat (Figure 3) and migratory species (Figure 4) maps that allow for visualization of turbine threat and key migratory species patterns and their potential interactions across the United States. Tabular datasets (full versions provided separately to PNNL, subsamples provided herein) were also produced that summarize, for each hydropower plant (Tables 3 and 4):

- the average turbine threat for the assemblage of turbines at each plant, 
- $\quad$ type of turbine installed at each plant ${ }^{1}$,

- the total number of key migratory species that occur within the 8-digit HUC of the plant,

- the nameplate capacity for generation potential at each plant,

- whether the facility operates under a license or is exempt,

- the license expiration date,

- the state where the plant is located,

- the 8-digit HUC where the plant is located, and

- a list of key migratory species that occur within the 8-digit HUC of the plant.

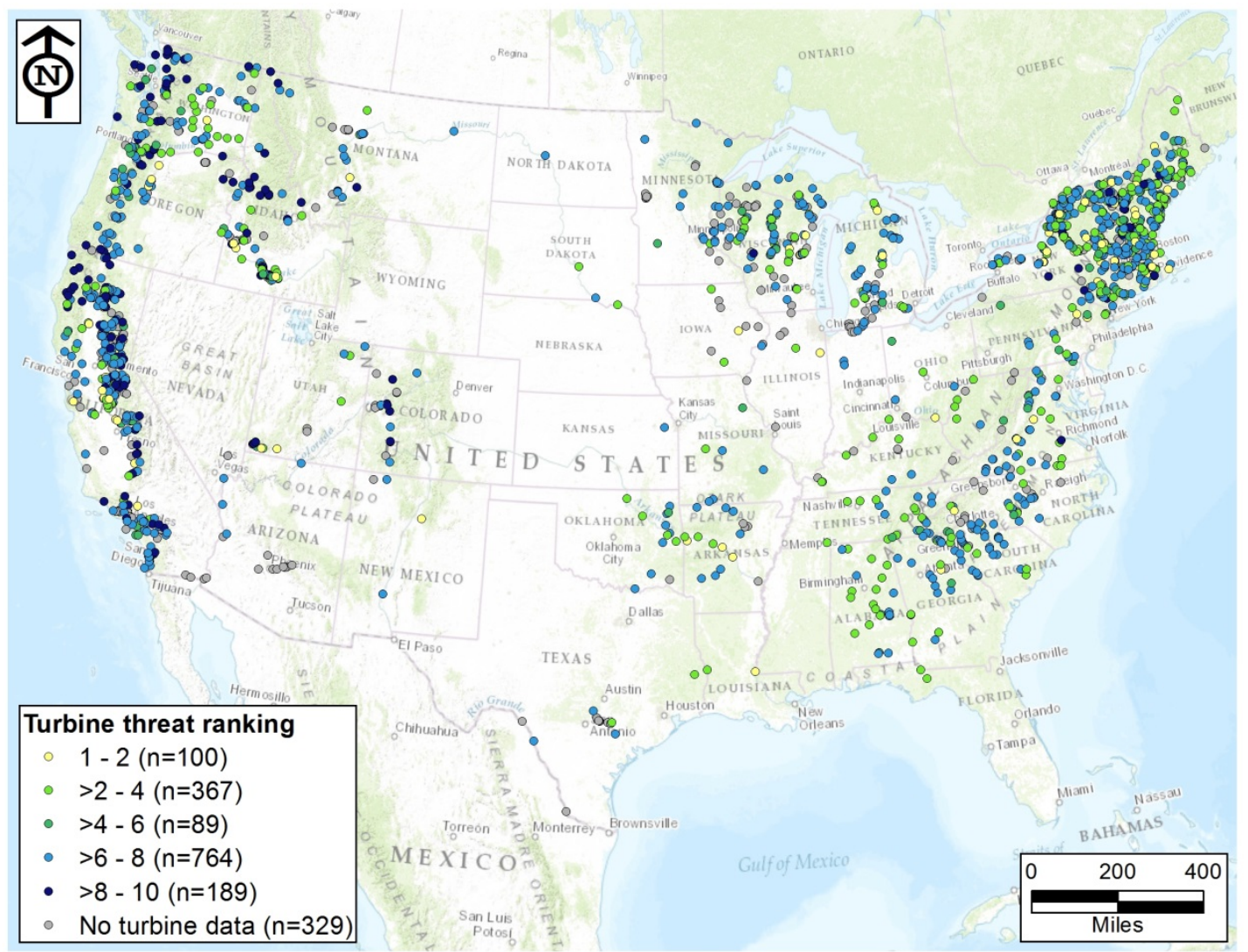

Figure 3. Average turbine threat ranking for hydropower plants.

${ }^{1}$ Only provided for subsample table in report; for full access to turbine types for plants across the United States, please contact Brennan Smith at smithbt@ornl.gov. 


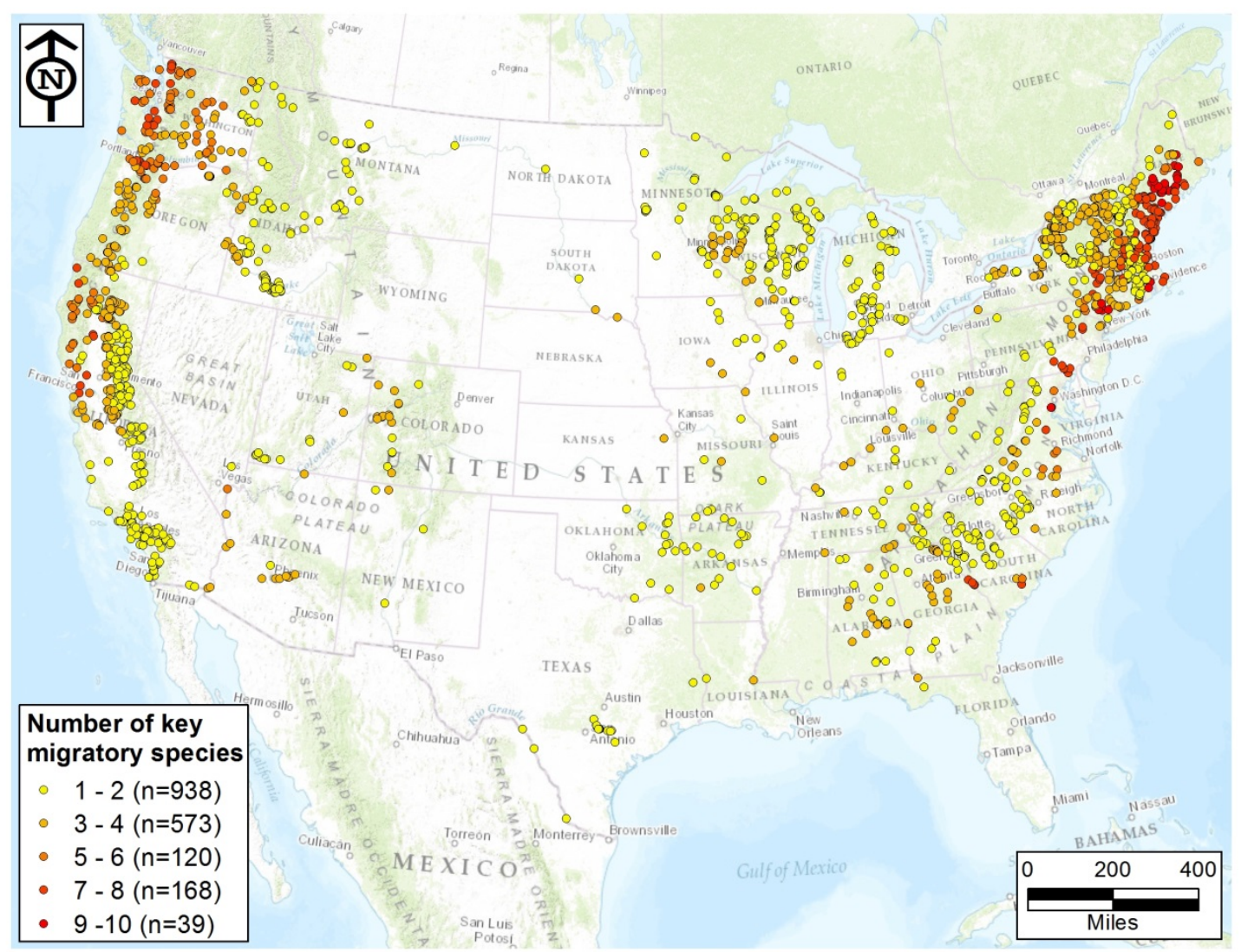

Figure 4. Number of key migratory species that have the potential to occur at each hydropower plant. 
Table 3. Example list of hydropower plants with relatively high turbine threat to fish, key migratory species occurrence potential, and generation capacity

\begin{tabular}{|c|c|c|c|c|c|c|c|c|}
\hline Plant name & Owner name & $\begin{array}{c}\text { Turbine } \\
\text { threat } \\
\text { (1 to 10) }\end{array}$ & $\begin{array}{c}\text { Total } \\
\text { KMS } \\
\text { in } \\
\text { HUC8 }\end{array}$ & $\begin{array}{l}\text { Nameplate } \\
\text { capacity } \\
\text { (MW) }\end{array}$ & $\begin{array}{c}\text { Years to } \\
\text { expiration }\end{array}$ & State & $\begin{array}{l}\text { Turbine } \\
\text { Type }\end{array}$ & $\begin{array}{c}\text { Plants in } \\
\text { top } 100 \\
\text { per } \\
\text { owner }\end{array}$ \\
\hline Grand Coulee & U S Bureau of Reclamation & 8.5 & 5 & 6,809 & ND & WA & Francis & 12 \\
\hline Chief Joseph & USACE Northwestern Division & 8.5 & 5 & 2,456 & ND & WA & Francis & 12 \\
\hline Hoover Dam & U S Bureau of Reclamation & 8.7 & 5 & 2,079 & ND & NV & Francis & 12 \\
\hline Muddy Run & Exelon Power & 7.0 & 8 & 1,072 & 1 & PA & Deriaz & 2 \\
\hline John Day & USACE Northwestern Division & 4.0 & 5 & 2,160 & ND & WA & Kaplan & 12 \\
\hline Glen Canyon Dam & U S Bureau of Reclamation & 8.5 & 4 & 1,312 & ND & $\mathrm{AZ}$ & Francis & 12 \\
\hline The Dalles & USACE Northwestern Division & 8.5 & 5 & 1,820 & ND & WA & Francis & 12 \\
\hline Robert Moses Niagara & New York Power Authority & 4.0 & 2 & 2,429 & 44 & NY & Kaplan & 3 \\
\hline Conowingo & Exelon Power & 6.7 & 8 & 533 & 1 & MD & Francis & 2 \\
\hline Wanapum & PUD No 2 of Grant County & 7.0 & 5 & 1,160 & 39 & WA & Deriaz & 2 \\
\hline Rocky Reach & PUD No 1 of Chelan County & 4.0 & 5 & 1,300 & 39 & WA & Kaplan & 2 \\
\hline Raccoon Mountain & Tennessee Valley Authority & 3.5 & 3 & 1,714 & ND & $\mathrm{TN}$ & Kaplan & 4 \\
\hline Bonneville & USACE Northwestern Division & 4.3 & 5 & 1,093 & ND & WA & ND & 12 \\
\hline Yards Creek & Jersey Central Power \& Lt Co & 4.0 & 8 & 453 & 40 & NJ & Kaplan & 1 \\
\hline McNary & USACE Northwestern Division & 8.5 & 5 & 991 & ND & WA & Francis & 12 \\
\hline Priest Rapids & PUD No 2 of Grant County & 8.5 & 5 & 956 & 39 & WA & Francis & 2 \\
\hline Ross & City of Seattle - (WA) & 8.5 & 6 & 450 & 12 & WA & Francis & 4 \\
\hline Edward C Hyatt & CA Dept. of Water Resource & 4.0 & 4 & 644 & -6 & CA & Kaplan & 3 \\
\hline J Strom Thurmond & USCE-Savannah District & 4.0 & 7 & 362 & ND & SC & Kaplan & 3 \\
\hline Bath County & Virginia Electric \& Power Co & 7.0 & 1 & 2,862 & 13 & VA & Deriaz & 1 \\
\hline Wells & PUD No 1 of Douglas County & 8.5 & 5 & 774 & 39 & WA & Francis & 1 \\
\hline Helms Pumped Storage & Pacific Gas \& Electric Co & 8.5 & 2 & 1,053 & 13 & CA & Francis & 4 \\
\hline Boundary & City of Seattle—(WA) & 7.0 & 2 & 1,040 & 42 & WA & Deriaz & 4 \\
\hline Bear Swamp & Brookfield Power New England & 4.0 & 4 & 600 & 7 & MA & Kaplan & 1 \\
\hline Northfield Mountain & First Light Power Res. Svcs. LLC & 8.5 & 2 & 940 & 5 & MA & Francis & 2 \\
\hline Safe Harbor & Safe Harbor Water Power Corp & 8.5 & 8 & 418 & 17 & PA & Francis & 1 \\
\hline Little Goose & USACE Northwestern Division & 8.5 & 4 & 810 & ND & WA & Francis & 12 \\
\hline Lower Granite & USACE Northwestern Division & 4.1 & 4 & 810 & ND & WA & Francis & 12 \\
\hline Lower Monumental & USACE Northwestern Division & 7.0 & 4 & 810 & ND & WA & Deriaz & 12 \\
\hline Mossyrock & City of Tacoma-(WA) & 4.0 & 6 & 300 & 24 & WA & Kaplan & 5 \\
\hline Brownlee & Idaho Power Co & 4.0 & 3 & 585 & -8 & ID & Kaplan & 3 \\
\hline Blenheim Gilboa & New York Power Authority & 4.0 & 2 & 1,000 & 6 & NY & Kaplan & 3 \\
\hline Hells Canyon & Idaho Power Co & 8.5 & 4 & 392 & -8 & OR & Francis & 3 \\
\hline Rock Island & PUD No 1 of Chelan County & 7.6 & 5 & 624 & 15 & WA & Deriaz & 2 \\
\hline Smith Mountain & Appalachian Power Co & 3.7 & 3 & 548 & 26 & VA & Bulb/Tub. & 1 \\
\hline Shasta & U S Bureau of Reclamation & 8.5 & 2 & 714 & ND & CA & Francis & 12 \\
\hline Ice Harbor & USACE Northwestern Division & 8.5 & 4 & 603 & ND & WA & Francis & 12 \\
\hline W R Gianelli & CA Dept. of Water Resource & 8.5 & 3 & 424 & ND & CA & Francis & 3 \\
\hline Richard B Russell & USCE-Savannah District & 8.5 & 2 & 628 & ND & $\mathrm{SC}$ & Francis & 3 \\
\hline
\end{tabular}

NOTES: ND = no data available; KMS = key migratory species; plants in this list were sorted based on the accumulation of turbine threat, KMS presence, and generation capacity rankings; the last column shows how many plants each owner owns in the top 100 ranked plants based on the sorting methodology. 
Table 4. Example list of key migratory species by plant

\begin{tabular}{|c|c|c|c|}
\hline Plant name & Owner name & Scientific name & Common name \\
\hline \multirow{5}{*}{ Grand Coulee } & \multirow{5}{*}{ US Bureau of Reclamation } & Acipenser transmontanus & White Sturgeon \\
\hline & & Oncorhynchus kisutch & Coho Salmon \\
\hline & & Oncorhynchus mykiss & Steelhead \\
\hline & & Oncorhynchus nerka & Sockeye Salmon \\
\hline & & Oncorhynchus tshawytscha & Chinook Salmon \\
\hline \multirow{5}{*}{ Chief Joseph } & \multirow{5}{*}{ USACE Northwestern Division } & Acipenser transmontanus & White Sturgeon \\
\hline & & Oncorhynchus kisutch & Coho Salmon \\
\hline & & Oncorhynchus mykiss & Steelhead \\
\hline & & Oncorhynchus nerka & Sockeye Salmon \\
\hline & & Oncorhynchus tshawytscha & Chinook Salmon \\
\hline \multirow{5}{*}{ Hoover Dam } & \multirow{5}{*}{ US Bureau of Reclamation } & Gila cypha & Humpback Chub \\
\hline & & Gila elegans & Bonytail \\
\hline & & Gila seminuda & Virgin River Chub \\
\hline & & Ptychocheilus lucius & Colorado Pikeminnow \\
\hline & & Xyrauchen texanus & Razorback Sucker \\
\hline \multirow{8}{*}{ Muddy Run } & \multirow{8}{*}{ Exelon Power } & Acipenser brevirostrum & Shortnose Sturgeon \\
\hline & & Acipenser oxyrinchus & Atlantic Sturgeon \\
\hline & & Alosa aestivalis & Blueback Herring \\
\hline & & Alosa mediocris & Hickory Shad \\
\hline & & Alosa sapidissima & American Shad \\
\hline & & Anguilla rostrata & American Eel \\
\hline & & Morone saxatilis & Striped Bass \\
\hline & & Petromyzon marinus & Sea Lamprey \\
\hline \multirow{5}{*}{ John Day } & \multirow{5}{*}{ USACE Northwestern Division } & Acipenser transmontanus & White Sturgeon \\
\hline & & Oncorhynchus kisutch & Coho Salmon \\
\hline & & Oncorhynchus mykiss & Steelhead \\
\hline & & Oncorhynchus nerka & Sockeye Salmon \\
\hline & & Oncorhynchus tshawytscha & Chinook Salmon \\
\hline
\end{tabular}

\section{DISCUSSION}

The goal of this analysis was to provide information and a tool to PNNL that could be used to expand the application space of the sensor fish by identifying hydropower plants that use turbines with a high potential to impact fish during downstream passage and that are located within the potential range(s) of key migratory species. Key attributes from the ORNL NHAAP database were used, along with nationalscale fish distributions, to create a dataset that can be queried to identify facilities that PNNL could contact regarding deployment of the sensor fish. Queries can be run on individual fields within the tabular datasets to target specific geographic regions (i.e., states), fish species, license expiration dates, generation capacity levels, ownership characteristics, turbine characteristics, or any combination of these metrics. Each continuous, numerical metric (e.g., turbine threats, number of key migratory species, and/or nameplate capacity) can also be transformed to a common value range, weighted if deemed desirable, and multiplied to rank plants based on an accumulation of multiple metrics. 
We included in the spreadsheet several filtering or sorting criteria that can be used to shorten the list of potential projects that might benefit from sensor fish application. The relevance of turbine type and hydraulic head were discussed earlier and are incorporated in the turbine risk score. Nameplate capacity is included with the presumption that higher generation capacity is closely related to the amount of water and therefore the number of fish passing through the turbines. Greater capacity also implies higher project revenues, which could mean a greater chance that the project owner can afford a sensor fish study. 'Years to Expiration' of the FERC license is included to identify those projects that will be in a stage of relicensing when studies are being planned that might benefit most from sensor fish deployment.

It should be noted that the NatureServe fish distribution data used in this study were derived at a relatively coarse national scale, so local-scale migration habits and/or habitat preferences of individual species were not accounted for in this analysis. Thus, the validity of species occurrences at specific facilities should be scrutinized based on professional knowledge of fish migration habits and habitat preferences in relation to specific dam locations.

In the analysis described in this letter report, the migratory species of concern were selected based on the experience of the authors and their knowledge as to which species have caused the most concern with regards to downstream fish passage. ORNL has also started a second approach that uses a traits-based analysis of fish vulnerability to turbine passage using the conceptual framework outlined by Cada and Schweizer (2012) to identify species of concern. By applying a traits-based assessment using a conceptual model that accounts for entrainment, passage, and population sustainability risks based on fish traits and turbine characteristics, more refined results can be achieved across the landscape and a more in-depth discretization of results can be performed. This approach might be completed in FY14 as part of the Biological Design Criteria project.

In addition to application at conventional hydropower dams, other types of waterpower, water conveyance, and water transfer systems should be considered as possible candidates for sensor fish testing. Several designs of hydrokinetic turbines are being tested for deployment in large river and tidal settings. One of the primary environmental concerns with these turbines is the impact to fish that pass through the turbine blades (Cada et al. 2007, EPRI 2011). These types of turbines do not produce a rapid change in pressure like that which occurs in conventional hydropower turbines, but blade strike and sheer are legitimate concerns. Studies of the potential impacts of hydrokinetic turbines have been difficult to conduct in the lab and field, and sensor fish technology might be able to answer questions that other forms of study have not been able to. Similar turbines are being tested in water conveyance canals and pipelines, but since these artificial conveyances seldom have fish populations of concern in them, the opportunity for application of sensor fish technology in these systems is probably minimal.

Large water withdrawal pumps, on the other hand, do sometimes operate in environments with sensitive fish populations, and minimizing entrainment or injury as a result of entrainment could be a problem that is solved by sensor fish application. Fish-friendly pumps developed by the Bureau of Reclamation are one example of designs that might benefit from sensor fish studies (USDOI-BUREC 2011). Fairbanks Nijhuis has developed a fish-friendly pump that is available in both vertical and horizontal configurations for both dry and wet mounting and has a default capacity that varies from 1,500 to $180,000 \mathrm{~m}^{3} / \mathrm{h}$. Bosman Watermanagement has also developed a fish-friendly pump, the Vision, which is designed to enable fish migration through a pumping station. The Vision is suitable for both new construction and renovation of pumping stations, is available in a range of standard modules, and has a reported capacity range of approximately $720-18,000 \mathrm{~m}^{3} / \mathrm{h}$. 


\section{REFERENCES}

Cada, G. F., C. C. Coutant, and R. R. Whitney. 1997. Development of Biological Design Criteria for the Design of Advanced Hydropower Turbines. DOE/ID-10578. Prepared for Office of Geothermal Technologies, U.S. DOE, Idaho Falls, Idaho.

Cada, G. F., J. Ahlgrimm, M. Bahleda, T. Bigford, S. Damiani Stavrakas, D. Hall, R. Moursund, and M. Sale. 2007. Potential Impacts of Hydrokinetic and Wave Energy Conversion Technologies on Aquatic Environments. Fisheries 32:174-181.

Cada, G. F. 2001. The Development of Advanced Hydroelectric Turbines to Improve Fish Passage Survival. Fisheries 26:14-23.

Cada, G. F. and P. E. Schweizer. 2012. The Application of Traits-Based Assessment Approaches to Estimate the Effects of Hydroelectric Turbine Passage on Fish Populations. ORNL/TM-2012/110. Oak Ridge National Laboratory, Oak Ridge, Tenn. p. 37.

Deng Z., T. J. Carlson, J. P. Duncan, and M. C. Richmond. 2007. Six-degree-of-freedom Sensor Fish Design and instrumentation. Sensors 7(12):3399-3415.

Deng Z., T. J. Carlson, J. P. Duncan, M. C. Richmond, and D. D. Dauble. 2010. Use of an Autonomous Sensor to Evaluate the Biological Performance of the Advanced Turbine at Wanapum Dam. Journal of Renewable and Sustainable Energy 2(5):053104. doi:10.1063/1.3501336.

EPRI. 2011. Fish Passage Through Turbines: Applicability of Conventional Hydropower Data to Hydrokinetic Technologies. EPRI, Palo Alto, Calif: 2011. Rpt. 1024638.

NatureServe. 2010. Digital Distribution Maps of the Freshwater Fishes in the Conterminous United States. Version 3.0. Arlington, Va. U.S.A.

ORNL (Oak Ridge National Laboratory). 2013. National Hydropower Asset Assessment Program. http://nhaap.ornl.gov/

USDOI-BUREC (US Department of the Interior/Bureau of Reclamation). 2011. Concept Level Design of a Fish-Friendly Pump System. Denver, Colo. Hydraulic Laboratory Technical Memorandum PAP1035. 